\title{
Tumor Evolution and Therapeutic Choice Seen through a Prism of Circulating Tumor Cell Genomic Instability
}

\author{
Tala Tayoun ${ }^{1,2,3}$, Marianne Oulhen ${ }^{1,2}$, Agathe Aberlenc ${ }^{1,2}$, Françoise Farace ${ }^{1,2, *}$ and Patrycja Pawlikowska ${ }^{2}$ \\ 1 Gustave Roussy, Université Paris-Saclay, “Circulating Tumor Cells” Translational Platform, \\ CNRS UMS3655-INSERM US23AMMICA, F-94805 Villejuif, France; tala.tayoun@gustaveroussy.fr (T.T.); \\ marianne.oulhen@gustaveroussy.fr (M.O.); agathe.aberlenc@gustaveroussy.fr (A.A.) \\ 2 Gustave Roussy, INSERM, U981 "Molecular Predictors and New Targets in Oncology", \\ F-94805 Villejuif, France; patrycjamarta.pawlikowska@gustaveroussy.fr \\ 3 Faculty of Medicine, Université Paris-Saclay, F-94270 Le Kremlin-Bicetre, France \\ * Correspondence: francoise.farace@gustaveroussy.fr; Tel.: +33-(14)-2115198
}

Citation: Tayoun, T.; Oulhen, M.; Aberlenc, A.; Farace, F.; Pawlikowska, P. Tumor Evolution and Therapeutic Choice Seen through a Prism of Circulating Tumor Cell Genomic Instability. Cells 2021, 10, 337. https://doi.org/10.3390/ cells10020337

Academic Editor:

Catherine Alix-Panabieres

Received: 13 January 2021

Accepted: 2 February 2021

Published: 5 February 2021

Publisher's Note: MDPI stays neutral with regard to jurisdictional claims in published maps and institutional affiliations.

Copyright: (C) 2021 by the authors Licensee MDPI, Basel, Switzerland. This article is an open access article distributed under the terms and conditions of the Creative Commons Attribution (CC BY) license (https:/ / creativecommons.org/licenses/by/ $4.0 /)$.

\begin{abstract}
Circulating tumor cells (CTCs) provide an accessible tool for investigating tumor heterogeneity and cell populations with metastatic potential. Although an in-depth molecular investigation is limited by the extremely low CTC count in circulation, significant progress has been made recently in single-cell analytical processes. Indeed, CTC monitoring through molecular and functional characterization may provide an understanding of genomic instability (GI) molecular mechanisms, which contribute to tumor evolution and emergence of resistant clones. In this review, we discuss the sources and consequences of GI seen through single-cell analysis of CTCs in different types of tumors. We present a detailed overview of chromosomal instability (CIN) in CTCs assessed by fluorescence in situ hybridization (FISH), and we reveal utility of CTC single-cell sequencing in identifying copy number alterations (CNA) oncogenic drivers. We highlight the role of CIN in CTC-driven metastatic progression and acquired resistance, and we comment on the technical obstacles and challenges encountered during single CTC analysis. We focus on the DNA damage response and depict DNArepair-related dynamic biomarkers reported to date in CTCs and their role in predicting response to genotoxic treatment. In summary, the suggested relationship between genomic aberrations in CTCs and prognosis strongly supports the potential utility of GI monitoring in CTCs in clinical risk assessment and therapeutic choice.
\end{abstract}

Keywords: circulating tumor cells; genomic instability; chromosomal instability; DNA-repair; tumor genetic heterogeneity

\section{Introduction}

Circulating tumor cells (CTC), present in peripheral blood of patients with cancers, are released from spatially distinct metastatic sites and primary tumor and thus may provide a comprehensive genomic picture of tumor content. The number of CTCs consists an independent prognostic factor and can be used to monitor treatment efficacy [1,2]. Alongside technological advances, CTCs have attracted clinical interest as a liquid biopsy to detect predictive biomarkers of sensitivity and resistance for therapy selection. Moreover, recent data on single CTC genomic analysis revealed the wide heterogeneity of CTCs, emphasizing the potential clinical utility of single CTC sequencing in identifying resistant clones that are arguably an important subset of cancer cells to target and eradicate. Indeed, growing evidence shows that CTCs may represent tumor phenotypic, genomic and transcriptomic heterogeneity and hence constitute a valuable sample to investigate tumor vulnerabilities. The phenotypes associated with tumor resistance and metastases require a complex pattern of cooperating processes among which genomic instability (GI) is a major actor. Oncogenic mutations as well as large-scale genomic alterations, copy number changes, DNA damage repair deficiencies or cell cycle perturbations may serve as an origin 
of GI and subsequent tumor heterogeneity. By offering real-time monitoring of a constantly evolving disease and by examining tumor GI through simple blood draws, CTCs may be of great utility to monitor patient response to treatment and precision medicine. Moreover, CTC-derived models have recently emerged as tractable platforms to explore functional capacities of CTCs.

In this review, we discuss different sources of GI and their impact on potential therapeutic solutions. We explore CTC genomic heterogeneity through fluorescence in situ hybridization (FISH) and single-cell sequencing and discuss how profiling of CTCs can be used to trace GI of tumors. We emphasize the importance of GI characterization in the context of tumor evolution and therapeutic choice. We outline the availability and utility of CDX models in functional characterization of tumor-adapted GI mechanisms. Finally, we highlight the dynamic changes of DNA-repair-related protein expression as functional biomarkers of GI and/or response to genotoxic treatment.

\section{Genomic Instability, More Than a Hallmark of Cancer}

Over the past few years, genomic studies have demonstrated the complex and heterogeneous landscape of cancer and its potential impact on treatment resistance and metastasis development. GI is a driving force promoting continuous modification of tumor genomes and leading to clonal evolution and tumor genomic heterogeneity. Alterations in the DNA damage response (DDR), endogenous and oncogene-induced replication stress or cell division deregulation promote GI in cancer (Figure 1).

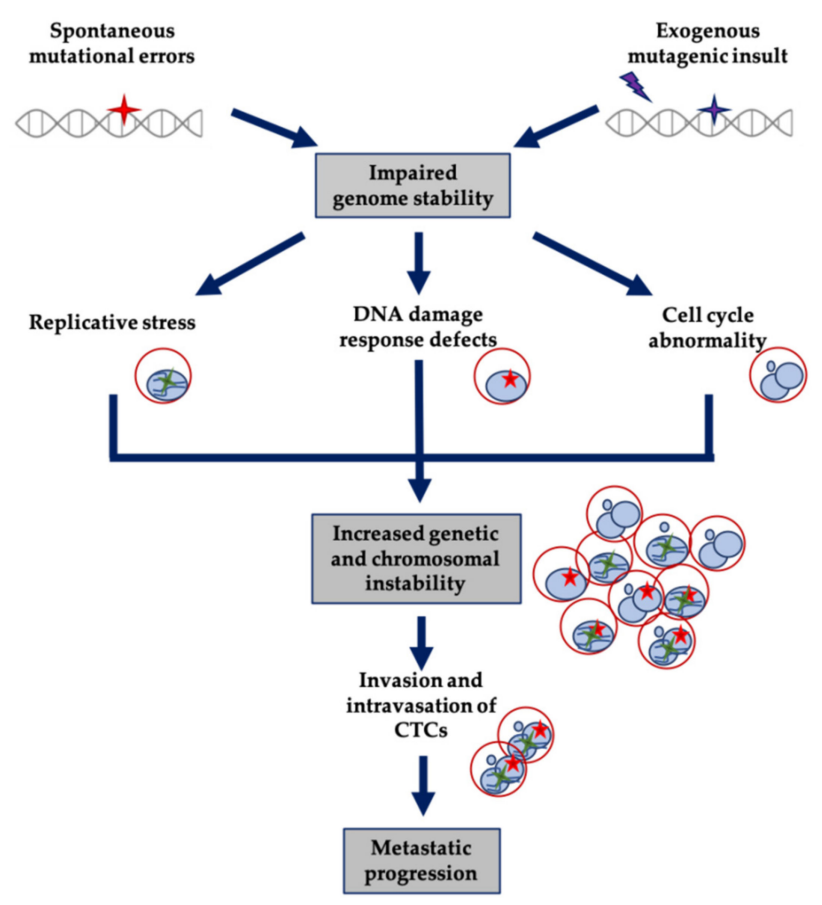

Figure 1. Concept diagram representing mechanisms of genome instability implicated in tumor evolution, including CTC contribution and their potential exploitation as biomarkers.

\subsection{DNA Damage Defects}

The DNA damage response (DDR) is a dynamic process based on the successive recruitments of different actors to DNA lesions. DNA damage occurs as a result of exogenous events such as ionizing irradiation or intercross-link agents, or as a part of perturbed physiological processes (see "Replicative stress" below). Resulting DNA double-strand breaks (DSBs) are the most cytotoxic lesions. Typically, two main repair mechanisms intervene to repair DSBs: homologous recombination (HR) and classical nonhomologous end joining. Histone $\mathrm{H} 2 \mathrm{AX}(\gamma \mathrm{H} 2 \mathrm{AX})$, Nijmegen breakage syndrome 1 (nibrin/NBS1) and mediator of DNA damage checkpoint protein 1 (MDC1) create a signal amplifica- 
tion loop adjacent to DSBs, which engages the recruitment of DDR proteins, including the MRN (MRE11-RAD50-NBS1) complex and breast cancer 1 (BRCA1) [3,4]. In-depth investigation of functional, "real time" biomarkers of DDR is crucial for monitoring this process under therapy. Phosphorylated $\gamma \mathrm{H} 2 \mathrm{AX}$ has emerged as a biomarker of DSBs, allowing the monitoring of genotoxic events [5]. Its expression also correlated with sensitivity to chemotherapy, radiotherapy, treatment with poly(ADP-ribose) polymerase (PARP) inhibitors (PARPi) and chemical genotoxicity [6,7].

Tumors deficient in one DNA repair pathway often rely on a compensatory mechanism to resolve the damage, i.e., fit their DNA-repair machinery, giving concomitantly potential opportunities for targeted therapeutic approaches. PARPi have demonstrated synthetic lethality in HR deficient BRCA1/BRCA2 mutant tumors, which led to their approval in platinum-sensitive (with/without BRCA1/2 mutation) ovarian cancer and in germline BRCA1/2 (gBRCA)-mutated metastatic breast cancer [8-10]. Germline gBRCA mutations remain the most common clinical biomarker for PARPi therapy response because BRCAmutant cells show clear evidence of HR deficiency. The prevalence and clinical relevance of somatic mutations in Fanconi anemia (FA) genes (23 FANC genes identified up to now) have been recently reported as "BRCAness", traits of sensitivity to PARPi treatment first identified in breast cancer and later acknowledged in other types of cancers [11]. Indeed, FA genes are commonly altered in several cancers. According to The Cancer Genome Atlas, alterations in FA genes (mutations, deletions, and amplifications) were detected in $40 \%$ of tumors [12]. The canonical function of FA proteins is to eliminate chromosome-breaking effect of intercross-linking agents and preserve genomic integrity by stabilizing replication forks, moderating RS and regulating mitotic division. Thus "BRCAness"-positive tumors are also frequently sensitive to platinum salts. However, amplifications of FA genes may be advantageous to cancer cells and contribute to resistance to chemotherapy. Deep deletions and loss-of-function mutations in DNA-repair-related genes may confer tumor sensitivity to DNA-repair-related targeted therapy. Recently, the potential utility of RAD51 protein, a surrogate marker of HR functionality, has been reported [13,14]. RAD51 assay performed in clinical practice on tumor tissue samples may improve patient selection for PARPi therapy in non-BRCA1/2-related cancers, which likewise present HR deficiency.

\subsection{Replicative Stress}

Any possible obstacle that disturbs DNA replication and prevents cells from finalizing their genome duplication before mitosis causes replicative stress (RS). It is a frequent phenomenon among cancer cells and is usually associated with structural chromosomal instability (CIN), which arises from prone to damage under-replicated DNA. Many cancers harbor persistent RS due to oncogene activation or compromised DNA-repair machinery in the absence or loss-of-function of essential that ensure protection or repair of stressed replication forks. Indeed, constitutive activation of oncogenes such as c-MYC, HRAS and KRAS has been shown to disturb the accurate DNA replication and has been associated with increased GI [15-17]. Recently, Wilhelm et al. proposed a mechanism through which RS contributed to numerical aneuploidy in both healthy and $\mathrm{CIN}^{+}$cancer cells, by driving chromosome mis-segregation via premature centriole disengagement [18]. This study was concordant with previously published observations where RS increased incidence of lagging chromosomes during cellular division $[19,20]$. Nonetheless, cancer cells cope with RS through different mechanisms, such as overexpression of checkpoint mediators Claspin and Timeless (members of ATR/CHK1 pathway), which may increase RS tolerance by protecting replication forks [21]. Therefore, similarly to DNA-repair-deficient tumors, RS response may also be exploited for cancer treatment.

\subsection{Cell Division Abnormality}

Mitotic CIN is defined as inability to faithfully segregate equal chromosome contents to two daughter cells during mitosis. Indeed, abnormal chromosome numbers or numerical aneuploidy is a common alteration in human cancer. It may be promoted by 
mitotic checkpoint deregulation and may lead to the loss of tumor suppressors or gain of oncogenic signals. However, the loss of key mitotic checkpoint genes is rare in clinical samples. Whole-genome doubling (WGD) induced through cytokinesis failure is a one-off event which may promote aneuploidy. Its prognostic utility has been first shown in earlystage colorectal cancer and was later proposed in other cancer types [22,23]. Tumor cells experiencing WGD have developed centrosome clustering as a mechanism to prevent lethal mitotic spindle multipolarity, by merging multiple centrosomes into two functional spindle poles. Interestingly, centrosome amplification stimulates cytoskeleton alterations, which might in turn be responsible for tumor cell invasions and thus metastatic development [24]. Inhibition of centrosome clustering may represent an anti-tumor specific strategy based on the formation of multipolar spindles and subsequent tumor cell death [25]. GI has also been associated with epithelial-mesenchymal transition (EMT) through the activation of the cytosolic DNA response pathway [26]. Indeed, altered chromosome segregation arising from GI promotes micronuclei formation whose rupture spills DNA into the cytosol. Presence of DNA in the cytosol induces the cGAS-STING (cyclic GMP-AMP synthase-stimulator of interferon genes) cytosolic DNA-sensing pathway and downstream noncanonical NF- $\mathrm{kB}$ signaling, thus inducing a proinflammatory response, which factors were recognized as EMT stimulators [27]. Identification of cGAS/STING activators is an area of active research, with several ongoing clinical trials evaluating such molecules [28,29].

Sequencing studies and mechanistic investigations have revealed alterations in GIrelated genes and events (e.g., TP53, BRCA1/2, RB1 loss, CDKN2A loss) relevant in cancer progression $[12,30]$. These have important clinical implications as they may give the possibility to better stratify the patients and help clinicians in therapy selection.

\section{GI-Related Biomarkers in CTCs and Their Utility for Clinical Decision Making}

In-depth assessment of GI in bulk biopsy sample is frequently incomplete due to limited sample availability, surrounding normal tissue contamination and tumor heterogeneity. Additionally, serial tumor tissue biopsies are not feasible in clinical practice and metastasis biopsies are limited to accessible sites. Blood-based liquid biopsies containing CTCs have emerged as a noninvasive and accessible alternative enabling serial sampling. CTC analysis is technically challenging due to their low prevalence in the bloodstream and their phenotypic heterogeneity. Nevertheless, several groups have recently illustrated the feasibility of single-cell profiling in CTCs, providing a spectrum of genomic alterations that may potentially represent tumor heterogeneity and unravel aggressive subclones. CTCs acquiring genomic alterations can initiate and drive selection of resistant clones responsible for tumor evolution and metastatic progression [31].

\subsection{CIN Analysis in CTCs by FISH}

FISH technique has been adopted as one of the main methods for the assessment of CIN status in tumors (reviewed by McGranahan et al. [32]). Variations in chromosome copy number across the cell population can be quantified using fluorescently labeled DNA probes that bind to the centromeres of specific chromosomes. In CTCs, FISH has been developed and optimized to detect biomarkers of sensitivity to selected treatments and better stratify the patients. However, research revealed an unforeseen aspect of chromosomal heterogeneity across CTCs. Indeed, one of the first successful applications of the FISH assay showed important CIN in prostate cancer ( $\mathrm{PCa}$ ) CTCs through the detection of heterogeneous chromosomal abnormalities among patients [33]. A study in castration-resistance prostate cancer (CRPC) showed that $E R G$ oncogene status was maintained in CTCs, while significant genetic heterogeneity was observed in AR copy number gain and PTEN loss. This suggested that ERG rearrangements might constitute an early event in prostate tumorigenesis [34]. In the multicentric PETRUS study of biomarker assessment, we reported phenotypic and FISH genetic heterogeneity of metastatic tumor tissue and CTCs in patients with CRPC [35]. High concordance between metastatic biopsies and CTCs for ERG-rearrangement was observed in spite of higher heterogeneity in CTCs. Other groups have also performed FISH analysis in metastatic 
CRPC CTCs revealing amplification of the $A R$ locus and MYC [36] as well as the presence of PCa-specific TMPRSS2-ERG fusion [37]. The comparative detection of $A L K$-rearranged CTCs in NSCLC patients and corresponding tumor tissue biopsies was also performed. In a cohort of 87 patients with lung adenocarcinoma, positive ALK immunostaining was reported in CTCs isolated from five patients, corresponding to the same patients presenting $A L K$-rearranged tumors [38]. Our group reported the detection of unique $A L K$ rearrangement patterns in CTCs in patients with metastatic NSCLC. Notably, we noted a high concordance in $A L K$ rearrangement patterns between CTCs and tumor biopsies in $18 \mathrm{ALK}$-positive and 14 $A L K$-negative patients. Additionally, the presence of a unique $A L K$ rearrangement pattern and EMT features was observed in CTCs [39]. Utility of ALK FISH testing in CTCs in the longitudinal follow-up of crizotinib resistance profiling was also demonstrated [40]. We showed that patients monitored at the early stage of crizotinib treatment presented significant correlation between dynamic evolution of the amount of $A L K$ copy number gained in CTCs and PFS, suggesting that increased CIN in CTCs may be associated with a worse outcome in ALK-rearranged NSCLC [41]. These reports consistently demonstrate that monitoring tumor genomic characteristics via CTCs FISH analysis may serve as a predictive biomarker of treatment efficacy in NSCLC patients.

In 2015, we reported the detection of rearrangement in the ROS1-tyrosine kinase gene (present in 1\% of NSCLC) in CTCs from ROS1-rearranged NSCLC patients. High levels of aneuploidy and numerical CIN have been proposed as a mechanism of genetic diversity in CTCs of ROS1-rearranged patients. DNA content quantifications and chromosome enumeration underscored increased CIN in CTCs [42]. Further studies based on FISH analysis emphasized CTC genomic heterogeneity through assessment of their numerical CIN. Another report demonstrated the assessment of MET amplification by FISH in CTCs from EGFR-mutated NSCLC patients at progression on erlotinib. MET amplification was detected in 3 of 39 samples but interestingly all MET-amplified CTCs were identified at disease progression [43]. Similarly, MET amplification was detected using FISH technique in CTCs of patients with gastric, colorectal and renal cancers following a capture of c-MET-expressing cells [44]. This particular aberration may have prognostic importance if confirmed, as c-MET protein overexpression increases distinctly in metastasis [45].

In breast cancer, assessment of HER2 status is considered as standard practice for therapy selection [46]. Interestingly, assessment of HER2 amplification using FISH in CTCs has been reported by several groups and may be used to stratify patients eligible to HER2targeted therapy [47-49]. PTEN gene loss may drive tumor progression through activation of PI3K/AKT pathway and occurs frequently in CRPC. PTEN gene status was assessed in CTCs using the Epic Sciences platform, which identifies CTCs through an algorithmbased image analysis followed by FISH [50,51]. PTEN losses determined by FISH in CTCs correlated with PTEN expression loss measured by IHC in corresponding tumors biopsies. They were also associated with worse prognosis in CRPC patients [50]. These FISH studies highlight the importance of serial CTC genomic analysis for the identification of biomarkers predictive of therapeutic efficacy in different cancer types. The data also emphasize heterogeneous CIN as a characteristic feature of CTCs from different tumor types and show the importance of single-cell analysis to evaluate CNA changes as possible mechanisms of resistance and/or tumor evolution. FISH analysis of tumor samples is in most cases still manually performed and is particularly laborious given the important number of hematopoietic cells still retained in enriched CTC fractions. Nevertheless, technological advancements in the field led to the development of semi-automated microscopy method that allows the identification of filtration-enriched CTCs from NSCLC and PCa patients and the detection of $A L K$, ROS1 and ERG gains and rearrangements in these cells, as we reported (Figure 2) [52]. Moreover, integrated subtraction enrichment and immunostaining FISH (SE-iFISH) was used to characterize CTCs of patients with malignancies such as nasopharyngeal carcinoma or esophageal cancer. Notably, CTC karyotyping allowed the assessment of chromosome 8 aneuploidy, which strongly associated with chemotherapy efficacy and prognosis $[53,54]$. Aforementioned studies show that although FISH has been 
developed to detect biomarkers of sensitivity to different selected treatments, it constitutes a valuable tool for the assessment of CIN across CTCs.

\subsection{Copy Number Alterations (CNA) Landscape to Describe CIN in CTCs}

The rarity and biological heterogeneity of CTCs have imposed technical challenges for their isolation and analyses at the single-cell level and impacted the success of robust processing of complex and costly downstream methodologies. The single-nucleus next-generation sequencing relies on successful whole genome amplification (WGA) of an individual cell to generate good-quality DNA for subsequent sequencing. All WGA systems generate nonlinear amplification bias, which may decrease genome coverage and thus needs to be taken into consideration during sequence analysis [55]. Reproducible CNA patterns among single CTCs and corresponding metastatic biopsy were obtained after multiple annealing and looping-based amplification cycles of WGA of single CTCs from lung cancer patients [56]. Indeed, each CTC from an individual patient exhibited reproducible CNA patterns similar to the metastatic tumor but not the primary tumor. This report also showed that different patients with adenocarcinoma shared similar CNA patterns, whereas patients with small-cell lung cancer (SCLC) had distinctly different CNA patterns. CNA profiling studies in the context of GI suggested that certain genomic loci may confer a selective advantage for metastasis through their action on different signaling pathways. To tackle the issue of protocol speed for clinical applications, Ferrarini et al. developed a single-tube method consisting of a single step, with ligation-mediated PCR (LM-PCR) WGA for low-pass whole genome sequencing and CNA calling from single cells [57]. This was adapted to analyze CTCs from patients with lung adenocarcinoma and PCa. The Ampli1 ${ }^{\mathrm{TM}}$ WGA-based low-pass workflow (Menarini Silicon Biosystems) successfully captured substantial heterogeneity across CTCs, highlighting the utility of single-cell profiling application for genome-informed therapeutic strategies [57]. Another group assessed GI through genome-wide copy number profiling of CTCs from seven metastatic CRPC patients [58]. CTCs were identified and characterized using the Epic Sciences CTC platform and subclonal tumor suppressor loss, oncogene amplification and GI were measured by the distribution of large-scale state transitions (LST) genome-wide (frequency of $\mathrm{CNV}$ breakpoints $>10 \mathrm{Mb}$ ). A broad range of copy number changes in $A R$ and PTEN were detected in most CRPC patients accompanied by high heterogeneity in LST distribution, highlighting important GI in CTCs at the single-cell resolution [58]. Additional CNA profiling studies in CRPC highlight high levels of genomic heterogeneity among CTCs $[59,60]$. The compound losses of three tumor suppressors (PTEN, RB1 and TP53) in PCa CTCs and the corresponding circulating tumor DNA analysis were recently reported and linked to the aggressive trait of the tumor [61]. Moreover, gains in PTK2 and MYC together with TP53 loss were also detected in CTCs and were strongly associated with poor prognosis in PCa patients. Despite frequent copy number traces that highly resembled corresponding biopsies, unique gains in $M Y C$ were revealed in CNA profiles of CTCs captured from apheresis of PCa patients [62]. Previously, MYCN gain and simultaneous $A R$ loss was proposed as a possible mechanism of neuroendocrine differentiation in PCa tumor samples [63] and was later confirmed in CTCs as part of highly complex profile containing additional aberrations in ERG, c-MET and PI3K genes during CRPC progression [59]. Evaluation of CNA profiles in CTCs from metastatic breast cancer patients suggested potentially targetable alterations in PTCH1 and NOTCH1 that were absent in baseline biopsies, indicating subclonal tumor evolution [64]. The predictive value of CNA profiles of CTCs has also been recently evidenced in SCLC patients. Characteristic CNA signature of subsequent chemosensitivity was reported with an $83.3 \%$ accuracy to classify SCLC CTCs as chemosensitive or chemorefractory [65]. Similarly, predictive single CTC-based CNA score in the response to first-line chemotherapy was demonstrated in SCLC patients by Su et al. CNA profiles across CTCs of individual SCLC patients were highly concordant with copy number losses in two frequently inactivated genes, TP53 and RB1, found in $64.6 \%$ and $81.3 \%$ of patients respectively [66]. 
A
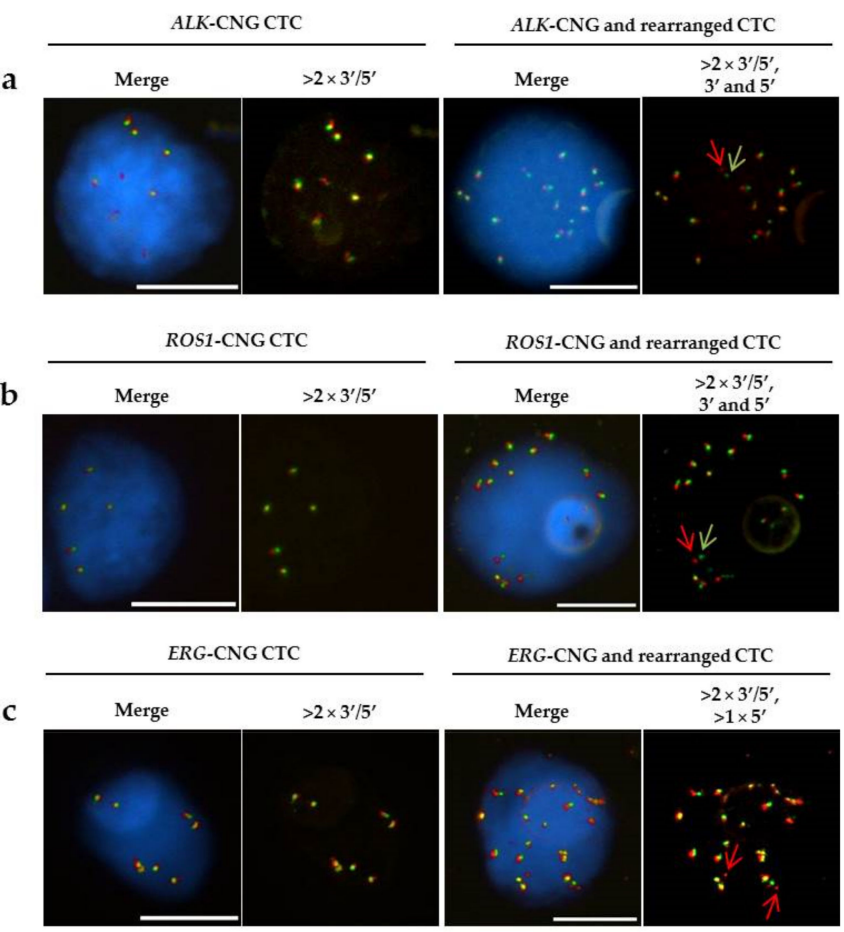

B

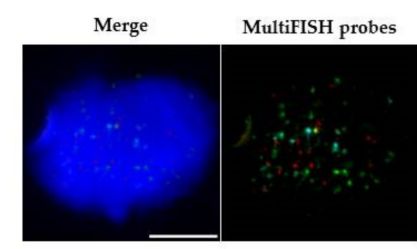

C

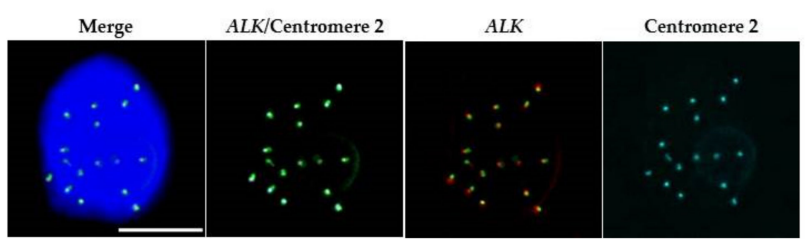

Figure 2. Detection of CTCs harboring $A L K$ and ROS-1 gene aberrations in NSCLC patients and $E R G$ gene alterations in metastatic CRPC patients by combined immunofluorescent staining and filter-adapted FISH (FA-FISH). (A). (a) Example of FISH patterns in NSCLC CTCs with ALK-copy number gain ( $A L K-C N G)$ and $A L K$-rearrangement. Red and green arrows correspond to $A L K 3^{\prime}$ and $A L K 5^{\prime}$ probes (Vysis $A L K$ Break Apart rearrangement Probe Kit from Abbott Molecular Inc., Chicago, IL, USA) respectively. (b) Example of FISH patterns in NSCLC CTCs bearing ROS1-CNG and ROS1rearrangement. Green and red arrows correspond to $3^{\prime}$ and $5^{\prime}$ ROS1-rearrangement extremities (Vysis 6q22 ROS1 Break Apart FISH probe RUO Kit from Abbott Molecular Inc.) respectively. (c) Example of FISH patterns in CRPC CTCs with ERG-CNG and ERG-rearrangement. Green and red arrows correspond to $3^{\prime}$ and $5^{\prime} E R G$ gene ends (Kreatech ERG Break Apart Rearrangement Probes kit) respectively. (B). Example of hybridized CTC using the AneuVysion Multicolor DNA Probe Kit (Abbott Molecular Inc.). Green spots indicate hybridization of locus-specific identification (LSI) 13 probe and centromere-specific enumeration probe (CEP) X. Red spots indicate hybridization of LSI 21 probe and CEP Y. Blue spots indicate hybridization of CEP 18. (C). Example of FISH patterns in CTCs with ALK-CNG detected by combined immunofluorescent staining and three-color FA-FISH for $A L K$ gene and chromosome 2 centromere detection (XCyting Centromere Enumeration Probe XCE2 from MetaSystems $\mathrm{GmbH}$ ), showing the existence of true gains of $A L K$ gene in CTCs. Scale: white bars $=10 \mu \mathrm{m}$. 
Overall, single-cell heterogeneity revealed by CNA analysis clearly represents a challenge for CTC molecular biomarker studies. Nevertheless, in-depth analysis of a sufficient number of CTCs may allow the profiling of characteristic CNA burden, which may be informative for future treatment strategies.

\subsection{Using CTC-Derived Models to Investigate GI Mechanisms}

Over the past decade, CTC-derived models have emerged as tractable tools to explore metastatic disease by studying the tumorigenic capacity of CTCs in several malignancies [67]. Despite technical challenges due to CTC rarity in the bloodstream, significant efforts were provided in the establishment of CTC-derived xenografts (CDX). The first one was generated in 2013 from breast cancer patient CTCs [68], while other groups reported successful models in lung, melanoma and prostate cancers [69-72]. We recently reported sequential acquisition of key genetic events promoting an aggressive neuroendocrine transformation in CRPC CDX. PTEN and RB1 losses were acquired in CTCs, while TP53 loss harbored in a subclone of the primary tumor was suggested as the driver of the metastatic event leading to CDX development. Interestingly, co-occurring losses of tumor suppressor genes PTEN, RB1 and TP53 were found in single CTCs characterized by extremely high CIN. Neuroendocrine transformation was promoted by the high number of CNAs and WGD, highlighting GI acquired during metastatic development [72]. In SCLC, single-cell analysis of CDX revealed the existence of co-existing heterogeneous cell subpopulations that are contributing to multiple concurrent resistance mechanism to chemotherapy [73]. Ex vivo expansion of viable CTCs has also been described [74-78]. Transcriptomic analysis of a CTC cell line derived from a metastatic colon cancer patient indicated altered expression of DNA-repair-related genes compared to a primary colon cancer cell line $[77,79]$. Another CTC-derived breast cancer cell line was recently established from a patient with metastatic estrogen receptor-positive breast cancer. Its CNA profile was highly concordant with that of patient CTCs and WES analysis deciphered alterations in common DNA damage-related genes (e.g., ATM, CDKN1A) [78].

The current time frame required for developing CTC-derived models does not allow for real-time monitoring of cancer patients and thus may not inform clinical decisions. However, their genomic analysis may help decipher molecular events involved in CTC-mediated tumor progression and reveal potential CTC biomarkers relevant for clinical management.

\subsection{DNA Repair-Related Protein Biomarkers in CTCs}

Functional analysis of DNA-repair-related protein expression in CTCs has been used as a pharmacodynamic biomarker for monitoring response to chemotherapy or targeted therapy (Table 1). Expression of DSB marker $\gamma \mathrm{H} 2 \mathrm{AX}$ has been evaluated as a dynamic indicator of DNA damage in CTCs from patients with advanced cancers after topotecan treatment using immunofluorescent staining followed by FACS analysis [80]. Data showed feasibility of monitoring dynamic changes in CTC nuclear biomarkers at response to treatment. $\gamma \mathrm{H} 2 \mathrm{AX}$ foci were also evaluated in CTCs after CellSearch analysis performed during radiation therapy as well as during combination treatment of low-dose of radiotherapy combined with PARPi $[81,82]$. Another DSB protein, RAD50, has been sequentially monitored in CTCs and its expression was estimated after radiotherapy of single side lesions in advanced lung cancer patients. CTCs were additionally screened for the immunotherapeutic target PD-L1 after enrichment with CellSieve Microfiltration Assay [83]. Results showed that RAD50 nuclear foci formation in CTCs may serve as a noninvasive tracer in cancer patients receiving side-directed radiotherapy independently of PD-L1 screening. ERCC excision repair 1 (ERCC1) is required for the repair of cisplatin-induced DNA lesions and may play the role of a biomarker for predicting response to platinum therapy. Indeed, it has been suggested that tumor cells overexpressing ERCC1 may be characterized with an enhanced capacity to resolve DNA platinum-adducts and consequently bypassing platinum cytotoxicity [84]. ERCC1 expression in CTCs was found to negatively correlate with PFS in metastatic NSCLC patients under platinum-based chemotherapy [85] and presence of CTCs 
expressing ERCC1 after therapy indicated a worse outcome for breast cancer patients [86]. Another group showed that ERCC1 transcript expression in CTCs was more predictive of response to platinum-based chemotherapy than standard ERCC1 protein expression detected on primary tumor biopsy samples [87]. Additionally, ERCC1 transcript-positive CTCs were used for monitoring platinum-based chemotherapy and to assess the post-therapeutic outcome of ovarian cancer [88]. These studies suggested that CTCs may represent dynamic intra-cellular changes in response to DNA-repair-related treatments more accurately than tumor biopsy. Furthermore, overexpression of the DNA/RNA helicase Schlafen family member 11 (SLFN11) has been described as an emerging biomarker of tumor cell sensitivity to DNA-damaging agents, including platinum chemotherapy [89] and to PARPi in several cancers [90,91]. SLFN11 protein expression was evaluated by immunofluorescent staining in CTCs from CRPC patients treated with platinum chemotherapy. SLFN11 overexpression in CTCs was associated with longer PFS compared to patients with SLFN11-negative CTCs [92]. Despite accumulating data, identification of CTC subpopulations expressing DNA-repair-related markers remains complex due to the existing variations among the technologies used to this end, as well as their low prevalence in patient blood. Therefore, further research is required to determine the clinical relevance of such biomarkers, notably in patients with advanced malignancies presenting significant levels of CTCs.

Table 1. DNA damage repair-related biomarkers in CTCs.

\begin{tabular}{|c|c|c|c|c|}
\hline $\begin{array}{l}\text { DNA Repair-Related } \\
\text { Protein Markers in CTCs }\end{array}$ & Tumor Type & Treatment & Key Findings & Ref. \\
\hline \multirow{3}{*}{$\begin{array}{l}\text { YH2AX (phosphorylated } \\
\text { Ser } 139 \mathrm{H} 2 \mathrm{AX} \\
\text { variant histone) }\end{array}$} & $\begin{array}{l}\text { Various advanced } \\
\text { cancers }\end{array}$ & Topotecan & $\begin{array}{c}\text { - A dose-dependent increase of } \\
\text { YH2AX-positive patient CTCs } \\
\text { with topotecan } \\
\text { - Monitoring of pharmacodynamics effects } \\
\text { of chemotherapy via nuclear YH2AX levels }\end{array}$ & [80] \\
\hline & NSCLC & Radiotherapy & $\begin{array}{l}\text { Elevated YH2AX signal in CTCs } \\
\text { post-radiotherapy }\end{array}$ & [81] \\
\hline & $\begin{array}{l}\text { Peritoneal cancers and } \\
\text { advanced solid } \\
\text { malignancies }\end{array}$ & $\begin{array}{l}\text { Radiotherapy and PARPi } \\
\text { (veliparib) }\end{array}$ & $\begin{array}{c}\text { - Exploratory study showing the use of } \\
\text { YH2AX in CTCs } \\
\text { - Increase in YH2AX }{ }^{+} \text {CTC levels after } \\
\text { treatment in few patients while one patient } \\
\text { presented a decrease, suggestive of } \\
\text { treatment failure }\end{array}$ & [82] \\
\hline $\begin{array}{l}\text { RAD50 (double strand } \\
\text { break repair protein) }\end{array}$ & NSCLC & Radiotherapy & $\begin{array}{l}\text { - RAD50 foci formation used to label and } \\
\text { track CTCs subjected to radiation at } \\
\text { primary site } \\
\text { - Monitoring of tumor dynamics }\end{array}$ & [83] \\
\hline \multirow{3}{*}{$\begin{array}{c}\text { ERCC1 } \\
\text { (Excision repair } \\
\text { cross-complementation } \\
\text { group 1) }\end{array}$} & NSCLC & Platinum chemotherapy & $\begin{array}{l}\text { Correlation between low ERCC1 } \\
\text { expression in CTCs and progression-free } \\
\text { survival after platinum-based therapies }\end{array}$ & [85] \\
\hline & Breast cancer & Neoadjuvant chemotherapy & $\begin{array}{c}\text { - 72\% of ERCC1-positive CTCs } \\
\text { after therapy } \\
\text { - No significant correlation between CTCs } \\
\text { and clinical parameters }\end{array}$ & [86] \\
\hline & Ovarian cancer & Platinum chemotherapy & $\begin{array}{c}\text { ERCC1-positive CTC at diagnosis } \\
\text { predictive of resistance to platinum-based } \\
\text { therapy }\end{array}$ & [87] \\
\hline $\begin{array}{l}\text { SLFN11 } \\
\text { (DNA/RNA helicase } \\
\text { Schlafen family } \\
\text { member 11) }\end{array}$ & CRPC & Platinum chemotherapy & $\begin{array}{l}\text { Potential use of SLFN11 expression in } \\
\text { CTCs for selection of patients with better } \\
\text { response to platinum therapy }\end{array}$ & [92] \\
\hline $\begin{array}{c}\text { RAD23B } \\
(\text { RAD23 homolog B) }\end{array}$ & Rectal cancer & $\begin{array}{l}\text { Radiation and 5-FU } \\
\text { Or } \\
\text { radiation and capecitabine }\end{array}$ & $\begin{array}{c}\text { Expression of thymidylate synthase } \\
\text { (TYMS) and RAD23B has predictive value } \\
\text { of nonresponse to neoadjuvant } \\
\text { chemoradiation }\end{array}$ & [93] \\
\hline
\end{tabular}




\section{Conclusions}

The study of GI-related biomarkers in CTCs is an emerging field, and their real-time monitoring may be useful in clinical decision making. The technical advances and robust CTC isolation methods may now allow us to capture phenotypic and genetic heterogeneity and, subsequently, to reconstitute tumor characteristics. The relationship between GI, prognosis and acquired resistance to treatment is very complex, and deciphering the molecular mechanisms contributing to GI in CTCs remains crucial. The advancements in FISH analysis have strongly contributed to the unveiling of increased CIN in CTCs and its potential role in resistance mechanisms. CNAs successfully assessed via single-cell sequencing of CTCs indicated various sources of GI, such as oncogene-induced replicative stress, cell-cycle-related genes alterations or WGD, suggesting a rationale for therapeutic options. Moreover, CNA events reveal common DNA-repair-related gene alterations detected across tumor types. Those DDR alterations increase GI and thus may constitute novel therapeutic targets. Single CTC sequencing may therefore provide insight into the mechanistic origins and consequences of DDR deficiency in cancer (Figure 3). Finally, CTC-based monitoring of DDR-related biomarkers was proven to inform about therapeutic progress, but it also indicates first signals of acquiring resistance. Therefore, though investigating GI mechanisms through CTC monitoring is challenging, it is becoming particularly useful for tracking tumor heterogeneity and may present a critical element for precision medicine.

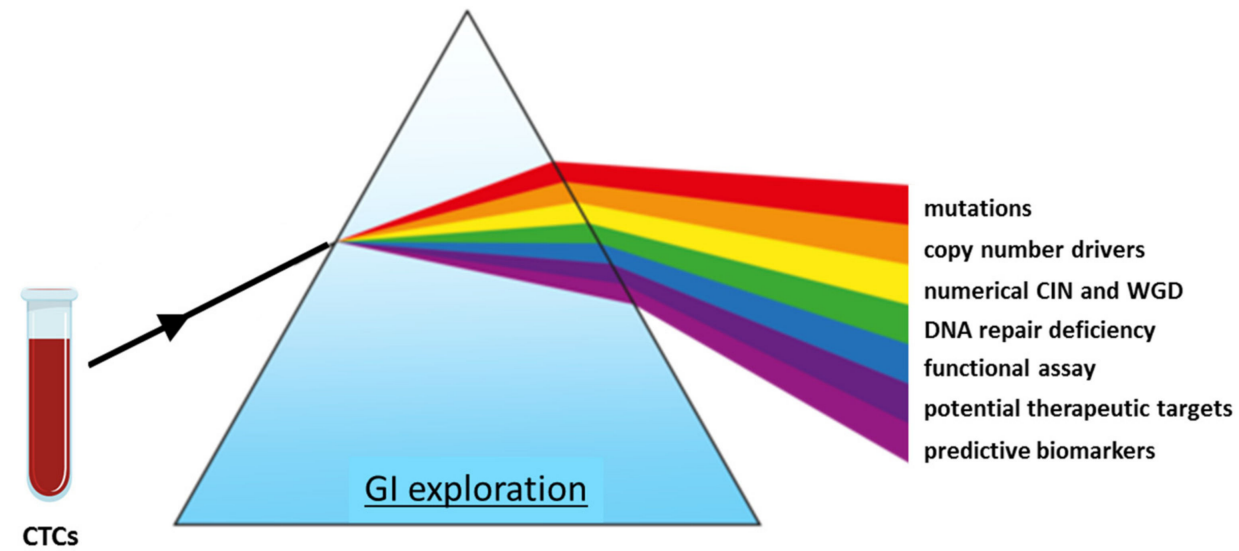

Figure 3. Schematic model of state-of-the-art strategies for the investigation of genome instability in CTCs.

Funding: T.T. is supported by La Ligue Nationale Contre le Cancer.

Institutional Review Board Statement: Not applicable.

Informed Consent Statement: Not applicable.

Data Availability Statement: Not applicable.

Acknowledgments: We are grateful to the patients and their families.

Conflicts of Interest: The authors declare no conflict of interest.

\section{References}

1. Bidard, F.-C.; Peeters, D.J.; Fehm, T.; Nolé, F.; Gisbert-Criado, R.; Mavroudis, D.; Grisanti, S.; Generali, D.; Garcia-Saenz, J.A.; Stebbing, J.; et al. Clinical Validity of Circulating Tumour Cells in Patients with Metastatic Breast Cancer: A Pooled Analysis of Individual Patient Data. Lancet Oncol. 2014, 15, 406-414. [CrossRef]

2. Lindsay, C.R.; Blackhall, F.H.; Carmel, A.; Fernandez-Gutierrez, F.; Gazzaniga, P.; Groen, H.J.M.; Hiltermann, T.J.N.; Krebs, M.G.; Loges, S.; López-López, R.; et al. EPAC-Lung: Pooled Analysis of Circulating Tumour Cells in Advanced Non-Small Cell Lung Cancer. Eur. J. Cancer 2019, 117, 60-68. [CrossRef] [PubMed] 
3. Kobayashi, J.; Antoccia, A.; Tauchi, H.; Matsuura, S.; Komatsu, K. NBS1 and Its Functional Role in the DNA Damage Response. DNA Repair 2004, 3, 855-861. [CrossRef]

4. Hari, F.J.; Spycher, C.; Jungmichel, S.; Pavic, L.; Stucki, M. A Divalent FHA/BRCT-Binding Mechanism Couples the MRE11RAD50-NBS1 Complex to Damaged Chromatin. EMBO Rep. 2010, 11, 387-392. [CrossRef] [PubMed]

5. Sharma, A.; Singh, K.; Almasan, A. Histone H2AX Phosphorylation: A Marker for DNA Damage. Methods Mol. Biol. 2012, 920, 613-626. [CrossRef] [PubMed]

6. Matthaios, D.; Hountis, P.; Karakitsos, P.; Bouros, D.; Kakolyris, S. H2AX a Promising Biomarker for Lung Cancer: A Review. Cancer Investig. 2013, 31, 582-599. [CrossRef]

7. Nagelkerke, A.; Span, P.N. Staining Against Phospho-H2AX ( $\gamma-\mathrm{H} 2 \mathrm{AX})$ as a Marker for DNA Damage and Genomic Instability in Cancer Tissues and Cells. Adv. Exp. Med. Biol. 2016, 899, 1-10. [CrossRef] [PubMed]

8. Kaufman, B.; Shapira-Frommer, R.; Schmutzler, R.K.; Audeh, M.W.; Friedlander, M.; Balmaña, J.; Mitchell, G.; Fried, G.; Stemmer, S.M.; Hubert, A.; et al. Olaparib Monotherapy in Patients with Advanced Cancer and a Germline BRCA1/2 Mutation. J. Clin. Oncol. 2015, 33, 244-250. [CrossRef] [PubMed]

9. Pujade-Lauraine, E.; Ledermann, J.A.; Selle, F.; Gebski, V.; Penson, R.T.; Oza, A.M.; Korach, J.; Huzarski, T.; Poveda, A.; Pignata, S.; et al. Olaparib Tablets as Maintenance Therapy in Patients with Platinum-Sensitive, Relapsed Ovarian Cancer and a BRCA1/2 Mutation (SOLO2/ENGOT-Ov21): A Double-Blind, Randomised, Placebo-Controlled, Phase 3 Trial. Lancet Oncol. 2017, 18, 1274-1284. [CrossRef]

10. Robson, M.; Im, S.-A.; Senkus, E.; Xu, B.; Domchek, S.M.; Masuda, N.; Delaloge, S.; Li, W.; Tung, N.; Armstrong, A.; et al. Olaparib for Metastatic Breast Cancer in Patients with a Germline BRCA Mutation. N. Engl. J. Med. 2017, 377, 523-533. [CrossRef]

11. Lord, C.J.; Ashworth, A. BRCAness Revisited. Nat. Rev. Cancer 2016, 16, 110-120. [CrossRef]

12. Knijnenburg, T.A.; Wang, L.; Zimmermann, M.T.; Chambwe, N.; Gao, G.F.; Cherniack, A.D.; Fan, H.; Shen, H.; Way, G.P.; Greene, C.S.; et al. Genomic and Molecular Landscape of DNA Damage Repair Deficiency across The Cancer Genome Atlas. Cell Rep. 2018, 23, 239-254.e6. [CrossRef] [PubMed]

13. Cruz, C.; Castroviejo-Bermejo, M.; Gutiérrez-Enríquez, S.; Llop-Guevara, A.; Ibrahim, Y.H.; Gris-Oliver, A.; Bonache, S.; Morancho, B.; Bruna, A.; Rueda, O.M.; et al. RAD51 Foci as a Functional Biomarker of Homologous Recombination Repair and PARP Inhibitor Resistance in Germline BRCA-Mutated Breast Cancer. Ann. Oncol. 2018, 29, 1203-1210. [CrossRef] [PubMed]

14. Castroviejo-Bermejo, M.; Cruz, C.; Llop-Guevara, A.; Gutiérrez-Enríquez, S.; Ducy, M.; Ibrahim, Y.H.; Gris-Oliver, A.; Pellegrino, B.; Bruna, A.; Guzmán, M.; et al. A RAD51 Assay Feasible in Routine Tumor Samples Calls PARP Inhibitor Response beyond BRCA Mutation. EMBO Mol. Med. 2018, 10. [CrossRef]

15. Gilad, O.; Nabet, B.Y.; Ragland, R.L.; Schoppy, D.W.; Smith, K.D.; Durham, A.C.; Brown, E.J. Combining ATR Suppression with Oncogenic Ras Synergistically Increases Genomic Instability, Causing Synthetic Lethality or Tumorigenesis in a Dosage-Dependent Manner. Cancer Res. 2010, 70, 9693-9702. [CrossRef] [PubMed]

16. Primo, L.M.F.; Teixeira, L.K. DNA Replication Stress: Oncogenes in the Spotlight. Genet Mol. Biol. 2019, 43, e20190138. [CrossRef]

17. Helbling-Leclerc, A.; Dessarps-Freichey, F.; Evrard, C.; Rosselli, F. Fanconi Anemia Proteins Counteract the Implementation of the Oncogene-Induced Senescence Program. Sci. Rep. 2019, 9, 17024. [CrossRef]

18. Wilhelm, T.; Olziersky, A.-M.; Harry, D.; De Sousa, F.; Vassal, H.; Eskat, A.; Meraldi, P. Mild Replication Stress Causes Chromosome Mis-Segregation via Premature Centriole Disengagement. Nat. Commun. 2019, 10. [CrossRef]

19. Wangsa, D.; Quintanilla, I.; Torabi, K.; Vila-Casadesús, M.; Ercilla, A.; Klus, G.; Yuce, Z.; Galofré, C.; Cuatrecasas, M.; Lozano, J.J.; et al. Near-Tetraploid Cancer Cells Show Chromosome Instability Triggered by Replication Stress and Exhibit Enhanced Invasiveness. FASEB J. 2018, 32, 3502-3517. [CrossRef]

20. Greil, C.; Krohs, J.; Schnerch, D.; Follo, M.; Felthaus, J.; Engelhardt, M.; Wäsch, R. The Role of APC/C(Cdh1) in Replication Stress and Origin of Genomic Instability. Oncogene 2016, 35, 3062-3070. [CrossRef]

21. Bianco, J.N.; Bergoglio, V.; Lin, Y.-L.; Pillaire, M.-J.; Schmitz, A.-L.; Gilhodes, J.; Lusque, A.; Mazières, J.; Lacroix-Triki, M.; Roumeliotis, T.I.; et al. Overexpression of Claspin and Timeless Protects Cancer Cells from Replication Stress in a CheckpointIndependent Manner. Nat. Commun. 2019, 10, 910. [CrossRef] [PubMed]

22. Dewhurst, S.M.; McGranahan, N.; Burrell, R.A.; Rowan, A.J.; Grönroos, E.; Endesfelder, D.; Joshi, T.; Mouradov, D.; Gibbs, P.; Ward, R.L.; et al. Tolerance of Whole-Genome Doubling Propagates Chromosomal Instability and Accelerates Cancer Genome Evolution. Cancer Discov. 2014, 4, 175-185. [CrossRef] [PubMed]

23. Jamal-Hanjani, M.; Wilson, G.A.; McGranahan, N.; Birkbak, N.J.; Watkins, T.B.K.; Veeriah, S.; Shafi, S.; Johnson, D.H.; Mitter, R.; Rosenthal, R.; et al. Tracking the Evolution of Non-Small-Cell Lung Cancer. N. Engl. J. Med. 2017, 376, 2109-2121. [CrossRef] [PubMed]

24. Godinho, S.A.; Picone, R.; Burute, M.; Dagher, R.; Su, Y.; Leung, C.T.; Polyak, K.; Brugge, J.S.; Thery, M.; Pellman, D. Oncogene-like Induction of Cellular Invasion from Centrosome Amplification. Nature 2014, 510, 167-171. [CrossRef] [PubMed]

25. Rhys, A.D.; Monteiro, P.; Smith, C.; Vaghela, M.; Arnandis, T.; Kato, T.; Leitinger, B.; Sahai, E.; McAinsh, A.; Charras, G.; et al. Loss of E-Cadherin Provides Tolerance to Centrosome Amplification in Epithelial Cancer Cells. J. Cell Biol. 2018, 217, 195-209. [CrossRef]

26. Bakhoum, S.F.; Ngo, B.; Laughney, A.M.; Cavallo, J.-A.; Murphy, C.J.; Ly, P.; Shah, P.; Sriram, R.K.; Watkins, T.B.K.; Taunk, N.K.; et al. Chromosomal Instability Drives Metastasis through a Cytosolic DNA Response. Nature 2018, 553, 467-472. [CrossRef]

27. Kwon, J.; Bakhoum, S.F. The Cytosolic DNA-Sensing CGAS-STING Pathway in Cancer. Cancer Discov. 2020, 10, 26-39. [CrossRef] 
28. Mullard, A. Can Innate Immune System Targets Turn up the Heat on "cold" Tumours? Nat. Rev. Drug Discov. 2018, 17, 3-5. [CrossRef]

29. Chabanon, R.M.; Muirhead, G.; Krastev, D.B.; Adam, J.; Morel, D.; Garrido, M.; Lamb, A.; Hénon, C.; Dorvault, N.; Rouanne, M.; et al. PARP Inhibition Enhances Tumor Cell-Intrinsic Immunity in ERCC1-Deficient Non-Small Cell Lung Cancer. J. Clin. Investig. 2019, 129, 1211-1228. [CrossRef]

30. Sanchez-Vega, F.; Mina, M.; Armenia, J.; Chatila, W.K.; Luna, A.; La, K.C.; Dimitriadoy, S.; Liu, D.L.; Kantheti, H.S.; Saghafinia, S.; et al. Oncogenic Signaling Pathways in The Cancer Genome Atlas. Cell 2018, 173, 321-337.e10. [CrossRef]

31. Gao, Y.; Ni, X.; Guo, H.; Su, Z.; Ba, Y.; Tong, Z.; Guo, Z.; Yao, X.; Chen, X.; Yin, J.; et al. Single-Cell Sequencing Deciphers a Convergent Evolution of Copy Number Alterations from Primary to Circulating Tumor Cells. Genome Res. 2017, 27, 1312-1322. [CrossRef]

32. McGranahan, N.; Burrell, R.A.; Endesfelder, D.; Novelli, M.R.; Swanton, C. Cancer Chromosomal Instability: Therapeutic and Diagnostic Challenges. EMBO Rep. 2012, 13, 528-538. [CrossRef] [PubMed]

33. Swennenhuis, J.F.; Tibbe, A.G.J.; Levink, R.; Sipkema, R.C.J.; Terstappen, L.W.M.M. Characterization of Circulating Tumor Cells by Fluorescence in Situ Hybridization. Cytom. A 2009, 75, 520-527. [CrossRef] [PubMed]

34. Attard, G.; Swennenhuis, J.F.; Olmos, D.; Reid, A.H.M.; Vickers, E.; A’Hern, R.; Levink, R.; Coumans, F.; Moreira, J.; Riisnaes, R.; et al. Characterization of ERG, AR and PTEN Gene Status in Circulating Tumor Cells from Patients with Castration-Resistant Prostate Cancer. Cancer Res. 2009, 69, 2912-2918. [CrossRef]

35. Massard, C.; Oulhen, M.; Le Moulec, S.; Auger, N.; Foulon, S.; Abou-Lovergne, A.; Billiot, F.; Valent, A.; Marty, V.; Loriot, Y.; et al. Phenotypic and Genetic Heterogeneity of Tumor Tissue and Circulating Tumor Cells in Patients with Metastatic Castrationresistant Prostate Cancer: A Report from the PETRUS Prospective Study. Oncotarget 2016, 7, 55069-55082. [CrossRef] [PubMed]

36. Leversha, M.A.; Han, J.; Asgari, Z.; Danila, D.C.; Lin, O.; Gonzalez-Espinoza, R.; Anand, A.; Lilja, H.; Heller, G.; Fleisher, M.; et al. Fluorescence in Situ Hybridization Analysis of Circulating Tumor Cells in Metastatic Prostate Cancer. Clin. Cancer Res. 2009, 15, 2091-2097. [CrossRef] [PubMed]

37. Danila, D.C.; Anand, A.; Sung, C.C.; Heller, G.; Leversha, M.A.; Cao, L.; Lilja, H.; Molina, A.; Sawyers, C.L.; Fleisher, M.; et al. TMPRSS2-ERG Status in Circulating Tumor Cells as a Predictive Biomarker of Sensitivity in Castration-Resistant Prostate Cancer Patients Treated With Abiraterone Acetate. Eur. Urol. 2011, 60, 897-904. [CrossRef] [PubMed]

38. Ilie, M.; Long, E.; Butori, C.; Hofman, V.; Coelle, C.; Mauro, V.; Zahaf, K.; Marquette, C.H.; Mouroux, J.; Paterlini-Bréchot, P.; et al. ALK-Gene Rearrangement: A Comparative Analysis on Circulating Tumour Cells and Tumour Tissue from Patients with Lung Adenocarcinoma. Ann. Oncol. 2012, 23, 2907-2913. [CrossRef] [PubMed]

39. Pailler, E.; Adam, J.; Barthélémy, A.; Oulhen, M.; Auger, N.; Valent, A.; Borget, I.; Planchard, D.; Taylor, M.; André, F.; et al. Detection of Circulating Tumor Cells Harboring a Unique ALK Rearrangement in ALK-Positive Non-Small-Cell Lung Cancer. J. Clin. Oncol. 2013, 31, 2273-2281. [CrossRef] [PubMed]

40. Tan, C.L.; Lim, T.H.; Lim, T.K.; Tan, D.S.-W.; Chua, Y.W.; Ang, M.K.; Pang, B.; Lim, C.T.; Takano, A.; Lim, A.S.-T.; et al. Concordance of Anaplastic Lymphoma Kinase (ALK) Gene Rearrangements between Circulating Tumor Cells and Tumor in Non-Small Cell Lung Cancer. Oncotarget 2016, 7, 23251-23262. [CrossRef] [PubMed]

41. Pailler, E.; Oulhen, M.; Borget, I.; Remon, J.; Ross, K.; Auger, N.; Billiot, F.; Ngo Camus, M.; Commo, F.; Lindsay, C.R.; et al. Circulating Tumor Cells with Aberrant ALK Copy Number Predict Progression-Free Survival during Crizotinib Treatment in ALK-Rearranged Non-Small Cell Lung Cancer Patients. Cancer Res. 2017, 77, 2222-2230. [CrossRef]

42. Pailler, E.; Auger, N.; Lindsay, C.R.; Vielh, P.; Islas-Morris-Hernandez, A.; Borget, I.; Ngo-Camus, M.; Planchard, D.; Soria, J.-C.; Besse, B.; et al. High Level of Chromosomal Instability in Circulating Tumor Cells of ROS1-Rearranged Non-Small-Cell Lung Cancer. Ann. Oncol. 2015, 26, 1408-1415. [CrossRef]

43. Yanagita, M.; Redig, A.J.; Paweletz, C.P.; Dahlberg, S.E.; O'Connell, A.; Feeney, N.; Taibi, M.; Boucher, D.; Oxnard, G.R.; Johnson, B.E.; et al. A Prospective Evaluation of Circulating Tumor Cells and Cell-Free DNA in EGFR-Mutant Non-Small Cell Lung Cancer Patients Treated with Erlotinib on a Phase II Trial. Clin. Cancer Res. 2016, 22, 6010-6020. [CrossRef]

44. Zhang, T.; Boominathan, R.; Foulk, B.; Rao, C.; Kemeny, G.; Strickler, J.H.; Abbruzzese, J.L.; Harrison, M.R.; Hsu, D.S.; Healy, P.; et al. Development of a Novel C-MET-Based CTC Detection Platform. Mol. Cancer Res. 2016, 14, 539-547. [CrossRef]

45. Shoji, H.; Yamada, Y.; Taniguchi, H.; Nagashima, K.; Okita, N.; Takashima, A.; Honma, Y.; Iwasa, S.; Kato, K.; Hamaguchi, T.; et al. Clinical Impact of C-MET Expression and Genetic Mutational Status in Colorectal Cancer Patients after Liver Resection. Cancer Sci. 2014, 105, 1002-1007. [CrossRef]

46. Mayer, J.A.; Pham, T.; Wong, K.L.; Scoggin, J.; Sales, E.V.; Clarin, T.; Pircher, T.J.; Mikolajczyk, S.D.; Cotter, P.D.; Bischoff, F.Z. FISH-Based Determination of HER2 Status in Circulating Tumor Cells Isolated with the Microfluidic CEE ${ }^{\mathrm{TM}}$ Platform. Cancer Genet. 2011, 204, 589-595. [CrossRef] [PubMed]

47. Munzone, E.; Nolé, F.; Goldhirsch, A.; Botteri, E.; Esposito, A.; Zorzino, L.; Curigliano, G.; Minchella, I.; Adamoli, L.; Cassatella, M.C.; et al. Changes of HER2 Status in Circulating Tumor Cells Compared with the Primary Tumor during Treatment for Advanced Breast Cancer. Clin. Breast Cancer 2010, 10, 392-397. [CrossRef] [PubMed]

48. Frithiof, H.; Aaltonen, K.; Rydén, L. A FISH-Based Method for Assessment of HER-2 Amplification Status in Breast Cancer Circulating Tumor Cells Following CellSearch Isolation. Onco Targets Ther. 2016, 9, 7095-7103. [CrossRef] [PubMed] 
49. Brouwer, A.; De Laere, B.; van Dam, P.-J.; Peeters, D.; Van Haver, J.; Sluydts, E.; El Moussaoui, A.; Mendelaar, P.; Kraan, J.; Peeters, M.; et al. HER-2 Status of Circulating Tumor Cells in a Metastatic Breast Cancer Cohort: A Comparative Study on Characterization Techniques. PLoS ONE 2019, 14, e0220906. [CrossRef]

50. Punnoose, E.A.; Ferraldeschi, R.; Szafer-Glusman, E.; Tucker, E.K.; Mohan, S.; Flohr, P.; Riisnaes, R.; Miranda, S.; Figueiredo, I.; Rodrigues, D.N.; et al. PTEN Loss in Circulating Tumour Cells Correlates with PTEN Loss in Fresh Tumour Tissue from Castration-Resistant Prostate Cancer Patients. Br. J. Cancer 2015, 113, 1225-1233. [CrossRef]

51. McDaniel, A.S.; Ferraldeschi, R.; Krupa, R.; Landers, M.; Graf, R.; Louw, J.; Jendrisak, A.; Bales, N.; Marrinucci, D.; Zafeiriou, Z.; et al. Phenotypic Diversity of Circulating Tumour Cells in Patients with Metastatic Castration-Resistant Prostate Cancer. BJU Int. 2017, 120, E30-E44. [CrossRef] [PubMed]

52. Pailler, E.; Oulhen, M.; Billiot, F.; Galland, A.; Auger, N.; Faugeroux, V.; Laplace-Builhé, C.; Besse, B.; Loriot, Y.; Ngo-Camus, M.; et al. Method for Semi-Automated Microscopy of Filtration-Enriched Circulating Tumor Cells. BMC Cancer 2016, 16. [CrossRef] [PubMed]

53. Zhang, J.; Shi, H.; Jiang, T.; Liu, Z.; Lin, P.P.; Chen, N. Circulating Tumor Cells with Karyotyping as a Novel Biomarker for Diagnosis and Treatment of Nasopharyngeal Carcinoma. BMC Cancer 2018, 18, 1133. [CrossRef] [PubMed]

54. Chen, Y.; Yang, Z.; Wang, Y.; Wang, J.; Wang, C. Karyotyping of Circulating Tumor Cells for Predicting Chemotherapeutic Sensitivity and Efficacy in Patients with Esophageal Cancer. BMC Cancer 2019, 19, 651. [CrossRef]

55. Zong, C.; Lu, S.; Chapman, A.R.; Xie, X.S. Genome-Wide Detection of Single-Nucleotide and Copy-Number Variations of a Single Human Cell. Science 2012, 338, 1622-1626. [CrossRef] [PubMed]

56. Ni, X.; Zhuo, M.; Su, Z.; Duan, J.; Gao, Y.; Wang, Z.; Zong, C.; Bai, H.; Chapman, A.R.; Zhao, J.; et al. Reproducible Copy Number Variation Patterns among Single Circulating Tumor Cells of Lung Cancer Patients. Proc. Natl. Acad. Sci. USA 2013, 110, 21083-21088. [CrossRef]

57. Ferrarini, A.; Forcato, C.; Buson, G.; Tononi, P.; Del Monaco, V.; Terracciano, M.; Bolognesi, C.; Fontana, F.; Medoro, G.; Neves, R.; et al. A Streamlined Workflow for Single-Cells Genome-Wide Copy-Number Profiling by Low-Pass Sequencing of LM-PCR Whole-Genome Amplification Products. PLoS ONE 2018, 13, e0193689. [CrossRef]

58. Greene, S.B.; Dago, A.E.; Leitz, L.J.; Wang, Y.; Lee, J.; Werner, S.L.; Gendreau, S.; Patel, P.; Jia, S.; Zhang, L.; et al. Chromosomal Instability Estimation Based on Next Generation Sequencing and Single Cell Genome Wide Copy Number Variation Analysis. PLOS ONE 2016, 11, e0165089. [CrossRef]

59. Gupta, S.; Li, J.; Kemeny, G.; Bitting, R.L.; Beaver, J.; Somarelli, J.A.; Ware, K.E.; Gregory, S.; Armstrong, A.J. Whole Genomic Copy Number Alterations in Circulating Tumor Cells from Men with Abiraterone or Enzalutamide-Resistant Metastatic CastrationResistant Prostate Cancer. Clin. Cancer Res. 2017, 23, 1346-1357. [CrossRef]

60. Hodara, E.; Morrison, G.; Cunha, A.; Zainfeld, D.; Xu, T.; Xu, Y.; Dempsey, P.W.; Pagano, P.C.; Bischoff, F.; Khurana, A.; et al. Multiparametric Liquid Biopsy Analysis in Metastatic Prostate Cancer. JCI Insight 2019, 4. [CrossRef]

61. Malihi, P.D.; Graf, R.P.; Rodriguez, A.; Ramesh, N.; Lee, J.; Sutton, R.; Jiles, R.; Ruiz Velasco, C.; Sei, E.; Kolatkar, A.; et al. Single-Cell Circulating Tumor Cell Analysis Reveals Genomic Instability as a Distinctive Feature of Aggressive Prostate Cancer. Clin. Cancer Res. 2020, 26, 4143-4153. [CrossRef]

62. Lambros, M.B.; Seed, G.; Sumanasuriya, S.; Gil, V.; Crespo, M.; Fontes, M.; Chandler, R.; Mehra, N.; Fowler, G.; Ebbs, B.; et al. Single-Cell Analyses of Prostate Cancer Liquid Biopsies Acquired by Apheresis. Clin. Cancer Res. 2018, 24, 5635-5644. [CrossRef]

63. Beltran, H.; Rickman, D.S.; Park, K.; Chae, S.S.; Sboner, A.; MacDonald, T.Y.; Wang, Y.; Sheikh, K.L.; Terry, S.; Tagawa, S.T.; et al. Molecular Characterization of Neuroendocrine Prostate Cancer and Identification of New Drug Targets. Cancer Discov. 2011, 1, 487-495. [CrossRef]

64. Paoletti, C.; Cani, A.K.; Larios, J.M.; Hovelson, D.H.; Aung, K.; Darga, E.P.; Cannell, E.M.; Baratta, P.J.; Liu, C.-J.; Chu, D.; et al. Comprehensive Mutation and Copy Number Profiling in Archived Circulating Breast Cancer Tumor Cells Documents Heterogeneous Resistance Mechanisms. Cancer Res. 2018, 78, 1110-1122. [CrossRef]

65. Carter, L.; Rothwell, D.G.; Mesquita, B.; Smowton, C.; Leong, H.S.; Fernandez-Gutierrez, F.; Li, Y.; Burt, D.J.; Antonello, J.; Morrow, C.J.; et al. Molecular Analysis of Circulating Tumor Cells Identifies Distinct Copy-Number Profiles in Patients with Chemosensitive and Chemorefractory Small-Cell Lung Cancer. Nat. Med. 2017, 23, 114-119. [CrossRef] [PubMed]

66. Su, Z.; Wang, Z.; Ni, X.; Duan, J.; Gao, Y.; Zhuo, M.; Li, R.; Zhao, J.; Ma, Q.; Bai, H.; et al. Inferring the Evolution and Progression of Small-Cell Lung Cancer by Single-Cell Sequencing of Circulating Tumor Cells. Clin. Cancer Res. 2019, 25, 5049-5060. [CrossRef]

67. Tayoun, T.; Faugeroux, O.; Aberlenc, P. Farace CTC-Derived Models: A Window into the Seeding Capacity of Circulating Tumor Cells (CTCs). Cells 2019, 8, 1145. [CrossRef] [PubMed]

68. Baccelli, I.; Schneeweiss, A.; Riethdorf, S.; Stenzinger, A.; Schillert, A.; Vogel, V.; Klein, C.; Saini, M.; Bäuerle, T.; Wallwiener, M.; et al. Identification of a Population of Blood Circulating Tumor Cells from Breast Cancer Patients That Initiates Metastasis in a Xenograft Assay. Nat. Biotechnol. 2013, 31, 539-544. [CrossRef]

69. Hodgkinson, C.L.; Morrow, C.J.; Li, Y.; Metcalf, R.L.; Rothwell, D.G.; Trapani, F.; Polanski, R.; Burt, D.J.; Simpson, K.L.; Morris, K.; et al. Tumorigenicity and Genetic Profiling of Circulating Tumor Cells in Small-Cell Lung Cancer. Nat. Med. 2014, 20 , 897-903. [CrossRef]

70. Morrow, C.J.; Trapani, F.; Metcalf, R.L.; Bertolini, G.; Hodgkinson, C.L.; Khandelwal, G.; Kelly, P.; Galvin, M.; Carter, L.; Simpson, K.L.; et al. Tumourigenic Non-Small-Cell Lung Cancer Mesenchymal Circulating Tumour Cells: A Clinical Case Study. Ann. Oncol. 2016, 27, 1155-1160. [CrossRef] [PubMed] 
71. Girotti, M.R.; Gremel, G.; Lee, R.; Galvani, E.; Rothwell, D.; Viros, A.; Mandal, A.K.; Lim, K.H.J.; Saturno, G.; Furney, S.J.; et al. Application of Sequencing, Liquid Biopsies, and Patient-Derived Xenografts for Personalized Medicine in Melanoma. Cancer Discov. 2016, 6, 286-299. [CrossRef]

72. Faugeroux, V.; Pailler, E.; Oulhen, M.; Deas, O.; Brulle-Soumare, L.; Hervieu, C.; Marty, V.; Alexandrova, K.; Andree, K.C.; Stoecklein, N.H.; et al. Genetic Characterization of a Unique Neuroendocrine Transdifferentiation Prostate Circulating Tumor Cell-Derived EXplant Model. Nat. Commun. 2020, 11, 1884. [CrossRef] [PubMed]

73. Stewart, C.A.; Gay, C.M.; Xi, Y.; Sivajothi, S.; Sivakamasundari, V.; Fujimoto, J.; Bolisetty, M.; Hartsfield, P.M.; Balasubramaniyan, V.; Chalishazar, M.D.; et al. Single-Cell Analyses Reveal Increased Intratumoral Heterogeneity after the Onset of Therapy Resistance in Small-Cell Lung Cancer. Nat. Cancer 2020, 1, 423-436. [CrossRef] [PubMed]

74. Zhang, Z.; Shiratsuchi, H.; Lin, J.; Chen, G.; Reddy, R.M.; Azizi, E.; Fouladdel, S.; Chang, A.C.; Lin, L.; Jiang, H.; et al. Expansion of CTCs from Early Stage Lung Cancer Patients Using a Microfluidic Co-Culture Model. Oncotarget 2014, 5, 12383-12397. [CrossRef] [PubMed]

75. Yu, M.; Bardia, A.; Aceto, N.; Bersani, F.; Madden, M.W.; Donaldson, M.C.; Desai, R.; Zhu, H.; Comaills, V.; Zheng, Z.; et al. Cancer Therapy. Ex Vivo Culture of Circulating Breast Tumor Cells for Individualized Testing of Drug Susceptibility. Science 2014, 345, 216-220. [CrossRef]

76. Gao, D.; Vela, I.; Sboner, A.; Iaquinta, P.J.; Karthaus, W.R.; Gopalan, A.; Dowling, C.; Wanjala, J.N.; Undvall, E.A.; Arora, V.K.; et al. Organoid Cultures Derived from Patients with Advanced Prostate Cancer. Cell 2014, 159, 176-187. [CrossRef] [PubMed]

77. Cayrefourcq, L.; Mazard, T.; Joosse, S.; Solassol, J.; Ramos, J.; Assenat, E.; Schumacher, U.; Costes, V.; Maudelonde, T.; Pantel, K.; et al. Establishment and Characterization of a Cell Line from Human Circulating Colon Cancer Cells. Cancer Res. 2015, 75, 892-901. [CrossRef]

78. Koch, C.; Kuske, A.; Joosse, S.A.; Yigit, G.; Sflomos, G.; Thaler, S.; Smit, D.J.; Werner, S.; Borgmann, K.; Gärtner, S.; et al. Characterization of Circulating Breast Cancer Cells with Tumorigenic and Metastatic Capacity. EMBO Mol. Med. 2020, 12, e11908. [CrossRef] [PubMed]

79. Alix-Panabières, C.; Cayrefourcq, L.; Mazard, T.; Maudelonde, T.; Assenat, E.; Assou, S. Molecular Portrait of MetastasisCompetent Circulating Tumor Cells in Colon Cancer Reveals the Crucial Role of Genes Regulating Energy Metabolism and DNA Repair. Clin. Chem. 2017, 63, 700-713. [CrossRef] [PubMed]

80. Wang, L.H.; Pfister, T.D.; Parchment, R.E.; Kummar, S.; Rubinstein, L.; Evrard, Y.A.; Gutierrez, M.E.; Murgo, A.J.; Tomaszewski, J.E.; Doroshow, J.H.; et al. Monitoring Drug-Induced GammaH2AX as a Pharmacodynamic Biomarker in Individual Circulating Tumor Cells. Clin. Cancer Res. 2010, 16, 1073-1084. [CrossRef] [PubMed]

81. Martin, O.A.; Anderson, R.L.; Russell, P.A.; Cox, R.A.; Ivashkevich, A.; Swierczak, A.; Doherty, J.P.; Jacobs, D.H.M.; Smith, J.; Siva, S.; et al. Mobilization of Viable Tumor Cells into the Circulation during Radiation Therapy. Int. J. Radiat. Oncol. Biol. Phys. 2014, 88, 395-403. [CrossRef] [PubMed]

82. Reiss, K.A.; Herman, J.M.; Zahurak, M.; Brade, A.; Dawson, L.A.; Scardina, A.; Joffe, C.; Petito, E.; Hacker-Prietz, A.; Kinders, R.J.; et al. A Phase I Study of Veliparib (ABT-888) in Combination with Low-Dose Fractionated Whole Abdominal Radiation Therapy in Patients with Advanced Solid Malignancies and Peritoneal Carcinomatosis. Clin. Cancer Res. 2015, 21, 68-76. [CrossRef] [PubMed]

83. Adams, D.L.; Adams, D.K.; He, J.; Kalhor, N.; Zhang, M.; Xu, T.; Gao, H.; Reuben, J.M.; Qiao, Y.; Komaki, R.; et al. Sequential Tracking of PD-L1 Expression and RAD50 Induction in Circulating Tumor and Stromal Cells of Lung Cancer Patients Undergoing Radiotherapy. Clin. Cancer Res. 2017, 23, 5948-5958. [CrossRef] [PubMed]

84. Chen, S.-H.; Chang, J.-Y. New Insights into Mechanisms of Cisplatin Resistance: From Tumor Cell to Microenvironment. Int. J. Mol. Sci. 2019, 20, 4136. [CrossRef]

85. Das, M.; Riess, J.W.; Frankel, P.; Schwartz, E.; Bennis, R.; Hsieh, H.B.; Liu, X.; Ly, J.C.; Zhou, L.; Nieva, J.J.; et al. ERCC1 Expression in Circulating Tumor Cells (CTCs) Using a Novel Detection Platform Correlates with Progression-Free Survival (PFS) in Patients with Metastatic Non-Small-Cell Lung Cancer (NSCLC) Receiving Platinum Chemotherapy. Lung Cancer 2012, 77, 421-426. [CrossRef]

86. Kasimir-Bauer, S.; Bittner, A.-K.; König, L.; Reiter, K.; Keller, T.; Kimmig, R.; Hoffmann, O. Does Primary Neoadjuvant Systemic Therapy Eradicate Minimal Residual Disease? Analysis of Disseminated and Circulating Tumor Cells before and after Therapy. Breast Cancer Res. 2016, 18, 20. [CrossRef] [PubMed]

87. Kuhlmann, J.D.; Wimberger, P.; Bankfalvi, A.; Keller, T.; Schöler, S.; Aktas, B.; Buderath, P.; Hauch, S.; Otterbach, F.; Kimmig, R.; et al. ERCC1-Positive Circulating Tumor Cells in the Blood of Ovarian Cancer Patients as a Predictive Biomarker for Platinum Resistance. Clin. Chem. 2014, 60, 1282-1289. [CrossRef]

88. Chebouti, I.; Kuhlmann, J.D.; Buderath, P.; Weber, S.; Wimberger, P.; Bokeloh, Y.; Hauch, S.; Kimmig, R.; Kasimir-Bauer, S. ERCC1Expressing Circulating Tumor Cells as a Potential Diagnostic Tool for Monitoring Response to Platinum-Based Chemotherapy and for Predicting Post-Therapeutic Outcome of Ovarian Cancer. Oncotarget 2017, 8, 24303-24313. [CrossRef]

89. Zoppoli, G.; Regairaz, M.; Leo, E.; Reinhold, W.C.; Varma, S.; Ballestrero, A.; Doroshow, J.H.; Pommier, Y. Putative DNA/RNA Helicase Schlafen-11 (SLFN11) Sensitizes Cancer Cells to DNA-Damaging Agents. Proc. Natl. Acad. Sci. USA 2012, 109, 15030-15035. [CrossRef] 
90. Barretina, J.; Caponigro, G.; Stransky, N.; Venkatesan, K.; Margolin, A.A.; Kim, S.; Wilson, C.J.; Lehár, J.; Kryukov, G.V.; Sonkin, D.; et al. The Cancer Cell Line Encyclopedia Enables Predictive Modelling of Anticancer Drug Sensitivity. Nature 2012, 483, 603-607. [CrossRef]

91. Lok, B.H.; Gardner, E.E.; Schneeberger, V.E.; Ni, A.; Desmeules, P.; Rekhtman, N.; de Stanchina, E.; Teicher, B.A.; Riaz, N.; Powell S.N.; et al. PARP Inhibitor Activity Correlates with SLFN11 Expression and Demonstrates Synergy with Temozolomide in Small Cell Lung Cancer. Clin. Cancer Res. 2017, 23, 523-535. [CrossRef]

92. Conteduca, V.; Ku, S.-Y.; Puca, L.; Slade, M.; Fernandez, L.; Hess, J.; Bareja, R.; Vlachostergios, P.J.; Sigouros, M.; Mosquera, J.M.; et al. SLFN11 Expression in Advanced Prostate Cancer and Response to Platinum-Based Chemotherapy. Mol. Cancer Ther. 2020, 19, 1157-1164. [CrossRef]

93. Troncarelli Flores, B.C.; Souza, E.; Silva, V.; Ali Abdallah, E.; Mello, C.A.L.; Gobo Silva, M.L.; Gomes Mendes, G.; Camila Braun, A.; Aguiar Junior, S.; Thomé Domingos Chinen, L. Molecular and Kinetic Analyses of Circulating Tumor Cells as Predictive Markers of Treatment Response in Locally Advanced Rectal Cancer Patients. Cells 2019, 8, 641. [CrossRef] 